\title{
A Fuzzy Assessment Index System on Undergraduates’ Employment Quality
}

\author{
Feng Du \\ School of Economics and Management, Beijing University of Technology, P.R. China
}

\begin{abstract}
With the highly development of China's economy and the popularization of higher education, the employment situation has never been so serious for college graduates due to various factors. Therefore, improving the quality of cultivating talents and fostering high-quality talents has turned to be the core of higher education development and also the fundamental prerequisites to improve international competitiveness. A set of evaluation index has been set up in the paper on employment quality taking full consideration of satisfaction degree of employees, satisfaction degree on employment guidance, personal employment preparation, practicability of course contents, and satisfaction degree on teaching. Modifications have also been carried out on the evaluation infrastructure and data with theory and methods of fuzzy mathematics. An empirical study has been laid at the end of the paper taking employment of undergraduates of Beijing University of Technology as an example.
\end{abstract}

Keywords-employment quality; index system; analytic hierarchy process; fuzzy assessment; membership matrix

\section{PRELUDE}

Since China's resumption of college entrance examination in 1978, the higher education in China has experienced a geometric growth. And the booming economy of China starting from the 1990s has put forward an increasing demand of highly educated human capital, and thus incurred an assignable gap between the university scale and social talent demand. A series of measurements have been adopted, including enlarging higher education scale and increasing enrollment, have been the key points of higher education reform in China to ease the tense ill balance between talent supply and demand. One of the fundamental changes is its shift of core from the elite mode to the mass mode, corresponding to the enrollment expanding policy of universities and colleges in 1999. The most practical problem facing policy makers now is whether the balance has been maintained between the supply and demand of highly educated talents, whereas the most practical answer lies in the employment quality evaluation of undergraduates. Those undergraduates may be confronted with multi options before the year of 1999, which is the very year after which, the initial employment ratios of undergraduates dropped to $75 \%$, with a gap of $25 \%$ reaching fully employment, which has called for wide social attentions. More seriously between 2008 and 2009, the worldwide financial crisis hammered down the initial employment ratio to less than $68 \%[1]$. All these require the universities and colleges to pay great attention to the influence of employment ratio and quality on enrollment scale and further consequences.

\section{LITERATURE REVIEW}

Various evaluation index systems on highly educated talents cultivation quality can be classified into two groups: one is that on the influencing factors, and the other on the inscapes.

Among the first group of researches, Ni et al suggested an index system including five major factors: university positioning accuracy, normalization of teaching, importance degree of practice, teaching evaluation and scientificalness of teaching methods[2].Xu et al presented some education methods in the process of graduation design in order to let undergraduates, in the last phase of education, gradually adapt the future employment[3]. Shao et al established the professional image of the brand discipline and teaching reform to ensure the quality of undergraduate education[4]. Base on the human oriented, comprehensive, coordinated and sustainable development quality view of talent cultivation, Sun and $\mathrm{Li}$ fabricated an evaluation system based on the ten factors of guiding ideology, teaching faculties, teaching condition, major and curriculum, teaching management, teaching and study style, teaching effect, and characteristic project[5]. Zhang built up one taking seven factors into consideration: teaching as center position, teaching input, learning autonomy, teaching model, learning state, multimedia teaching effect, and moral education[6].Dong et al expounded the necessity of enhancing the employability of undergraduates with measures like highlighting practice, training the students' employment skills and so on[7 ].

Among the second, Nguyen et al explored students' perceptions of the needs of employers in relation to satisfaction with their courses, job opportunities, and sources of their personal qualities[8].Liu proposed that quantitative evaluation system of employment quality should include three main contents: the evaluating indices system, the valuating standard, and the score table for evaluation[9]. Ke introduced five primary level indicators and ten secondary level indicators to establish employment quality evaluation system[10]. Zhang set up an index system based on seven first level indicators on inscapes of talent cultivation: optimization of curriculum system and teaching contents, basic quality of teaching faculty, basic quality of undergraduates at entrance, quality of theoretical teaching, professional practice, and conditions of running a school[11]. Zhang introduced another one based on safeguard system for cultivation, including index on employment ratio, salary, satisfaction degrees of both graduates and employers, brand awareness of universities and majors etc[12]. Dai and Cai[13], Sun[14] and Zhou[15] also provided different accesses to cultivation evaluation of 
universities and colleges with differed understandings on its components and connotations. Jia carried out comprehensive evaluation from the aspects of employment rate, salary level, social assurance, professional stability, professional structure and mental satisfaction degree to measure the teaching quality and capacity-building of non-governmental higher vocational colleges[16]. Yang et al judged the quality of employment by five dimensions, which are out of personal, family, social, college and employer satisfaction[17]. Li et al investigated effects of research and innovation ability on employment and methods to enhance the competitiveness of research skills[18]. $\mathrm{Li}$ strived for an effective career planning method to enhance the competitiveness of students and improve the quality of employment[19 ].

Evaluating indicators could only be built upon combinations of evaluating targets and methods, whereas an objective and scientific one could not only brings about a correct judgement but also guide to a continuous development of higher education. The talents cultivation of higher education should be based on principles of human oriented and promoting all-around development, with focus on knowledge imparting, ability training and quality improvement, and thus the corresponding evaluating index should have its cornerstones in knowledge, ability and quality with consideration of its feasibility.

\section{SETting UP OF THE EVALUATION INDEX ON EMPLOYMENT QUALITY}

A fuzzy evaluation index system on university undergraduates is to be presented in this paper, followed by an empirical study with Beijing University of Technology as an example.

\section{A. Index Set}

Influencing factors on employment quality of undergraduates are to be classified into to two groups of main factors and sub factors. The influencing factors are here actually the index set to be evaluated as , which include five first level indicators: satisfaction degree of employers, satisfaction degree on career guidance, personal preparation, practicability of teaching contents and satisfaction degree on teaching. This setting has taken consideration of teaching and career guidance of universities, personal motivation in employment of undergraduates, and social acceptance of the employers in three different dimensions, following the procedures of education and employment under the principles of logic and sequence, as shown in Table1.

TABLE I. INDEX SET OF EMPLOYMENT QUALITY OF GRADUATES

\begin{tabular}{|c|c|}
\hline 1st level indicator & 2nd level indicator \\
\hline \multirow{4}{*}{$\begin{array}{c}\text { Satisfaction degree of } \\
\text { employers }\end{array}$} & Wages \\
\cline { 2 - 2 } & Welfare \\
\cline { 2 - 2 } & Working environment \\
\cline { 2 - 2 } & Colleague relationship \\
\cline { 2 - 2 } & Management \\
\hline
\end{tabular}

\begin{tabular}{|c|c|}
\hline & Promotion mechanism \\
\hline \multirow{2}{*}{$\begin{array}{l}\text { Satisfaction degree on } \\
\text { career guidance }\end{array}$} & University level \\
\hline & School level \\
\hline \multirow{5}{*}{ Personal preparation } & Career guidance \\
\hline & Knowing of employment policies \\
\hline & Knowing of employment services \\
\hline & $\begin{array}{c}\text { Knowing of student employment } \\
\text { associations }\end{array}$ \\
\hline & Credibility and integrity \\
\hline \multirow{5}{*}{$\begin{array}{l}\text { Practicability of teaching } \\
\text { contents }\end{array}$} & Knowledge structure \\
\hline & Professional knowledge \\
\hline & Basic skills \\
\hline & Independent working ability \\
\hline & Inter person skills \\
\hline \multirow{6}{*}{$\begin{array}{l}\text { Satisfaction degree on } \\
\text { teaching }\end{array}$} & Problem analysis and solving \\
\hline & Creativity \\
\hline & Knowledge development \\
\hline & $\begin{array}{l}\text { Depth and breadth of professional } \\
\text { knowledge }\end{array}$ \\
\hline & Basic skills and practical ability \\
\hline & Formation of values \\
\hline
\end{tabular}

\section{B. Evaluation Set}

Let $V=\left(v_{1}, v_{2}, \ldots, v_{k}\right)$ be the evaluation set, in which $k$ is the number of evaluations. Lester scale is adopted in this paper to have the evaluations be classified into five scales as: hazard, poor, general, good and ideal.

\section{Weight Set}

Let $\underset{\sim}{B}=\left(b_{1}, b_{2}, \ldots, b_{k}\right) \in \wp(V)$ be one fuzzy sub set of $V$, in which $b_{h},(h=1,2, \ldots, k)$, indicating the position of the $h$ th evaluation in the overall one. And it is indeed the degree of membership of $v_{h}$ to the fuzzy set $\underset{\sim}{B}, \underset{\sim}{B}\left(v_{h}\right)=b_{h}$. The overall evaluation depends on the weight of each indicator which is the fuzzy sub set $W=\left(w_{1}, w_{2}, \ldots, w_{m}\right) \in \wp(U)$ on $U$, while $\sum_{i=1}^{m} w_{i}=1$, in which $w_{i}$ refers to the weight of the $i$ th factor. It is clear that an overall evaluation $\underset{\sim}{B}$ shall be reached once given the weight $W$. The approach of analytic hierarchy process (AHP) is engaged in this paper for the decision of weights, due to the reasons that AHP could not only guarantees the systematic and reasonable properties of the evaluating model, but also helps the decision makers taking fully advantage of their experiences and judgements. 
TABLE II. WEIGHT SET OF EVALUATING INDICATORS OF EMPLOYMENT QUALITY OF GRADUATES

\begin{tabular}{|c|c|c|c|}
\hline $\begin{array}{c}\text { 1st level } \\
\text { indicator }\end{array}$ & $\begin{array}{c}\text { 1st level } \\
\text { weight }\end{array}$ & 2nd level indicator & $\begin{array}{c}\text { 2nd level } \\
\text { weight }\end{array}$ \\
\hline \multirow{6}{*}{$\begin{array}{l}\text { Satisfaction } \\
\text { degree of } \\
\text { employers }\end{array}$} & \multirow{6}{*}{0.198} & Wages & 0.033 \\
\hline & & Welfare & 0.033 \\
\hline & & Working environment & 0.033 \\
\hline & & $\begin{array}{l}\text { Colleague } \\
\text { relationship }\end{array}$ & 0.033 \\
\hline & & Management & 0.033 \\
\hline & & $\begin{array}{l}\text { Promotion } \\
\text { mechanism }\end{array}$ & 0.033 \\
\hline \multirow{2}{*}{$\begin{array}{c}\text { Satisfaction } \\
\text { degree on } \\
\text { career } \\
\text { guidance } \\
\end{array}$} & \multirow[b]{2}{*}{0.247} & University level & 0.185 \\
\hline & & School level & 0.062 \\
\hline \multirow{5}{*}{$\begin{array}{c}\text { Personal } \\
\text { preparation }\end{array}$} & \multirow{5}{*}{0.198} & Career guidance & 0.101 \\
\hline & & Employment policies & 0.026 \\
\hline & & Employment services & 0.052 \\
\hline & & $\begin{array}{c}\text { Employment } \\
\text { associations }\end{array}$ & 0.010 \\
\hline & & $\begin{array}{c}\text { Credibility and } \\
\text { integrity }\end{array}$ & 0.008 \\
\hline \multirow{5}{*}{$\begin{array}{l}\text { Practicability } \\
\text { of teaching } \\
\text { contents }\end{array}$} & \multirow{5}{*}{0.198} & Knowledge structure & 0.007 \\
\hline & & $\begin{array}{c}\text { Professional } \\
\text { knowledge }\end{array}$ & 0.013 \\
\hline & & Basic skills & 0.026 \\
\hline & & Independent abilities & 0.052 \\
\hline & & Inter person skills & 0.101 \\
\hline \multirow{6}{*}{$\begin{array}{l}\text { Satisfaction } \\
\text { degree on } \\
\text { teaching }\end{array}$} & \multirow{6}{*}{0.159} & Problem solving & 0.022 \\
\hline & & Creativity & 0.005 \\
\hline & & $\begin{array}{c}\text { Knowledge } \\
\text { development }\end{array}$ & 0.005 \\
\hline & & $\begin{array}{c}\text { professional } \\
\text { knowledge }\end{array}$ & 0.011 \\
\hline & & $\begin{array}{c}\text { Basic skills \& } \\
\text { abilities }\end{array}$ & 0.041 \\
\hline & & Formation of values & 0.075 \\
\hline
\end{tabular}

The weights of the 1st and 2nd level indicators are gained through the AHP process and algorithm as shown in Tab.2, providing weight set for further fuzzy evaluation. It also shows the ill balance between impacts of teaching and personal preparation on employment quality. The six 2nd level indicators under the 1st level indicator "satisfaction degree of employer" enjoy equivalent weight proving that these six 2nd level indicators are of equal importance. The weight of "university level" is almost three times as large as that of "school level" under the 1st level indicator "satisfaction degree of career guidance" showing that the present career guidance is mainly carried out by universities with larger influences. Indicator "career guidance" has the largest weight under the 1st level indicator of "personal preparation" leading to that personal motivation has larger influence on employment quality than different sources of employment. "Inter person skills" is the dominant one under "practicability of teaching contents" revealing that the undergraduate's adapt to the society is of vital importance. The status of "formation of values" in "satisfaction degree on teaching" brings to light that moral education is the core of talents cultivation in higher education.

The fuzzy evaluation matrix is obtained through the procedure of balanced scoreboard model on the basis of this weight set, providing the possibilities of 1st level and overall fuzzy evaluations.

\section{FuZZY EVALUATION}

One of the most effective ways to reach a thorough evaluation on that under multivariant influence is fuzzy evaluation, which is normally carried out in two steps: single factor evaluation followed by comprehensive one covering all factors. This approach is easy to handle with good feasibility leading to satisfying evaluation result on multivariant and multilevel objects. Through judgement on each pair, unique evaluation of estimate is obtained for every judge object without any influence from the rest of the object set.

\section{A. Formation of the Fuzzy Evaluation Matrix}

The judgement $f\left(u_{i}\right)$ on every factor $u_{i}$ can be referred to as the fuzzy mapping $\underset{\sim}{f}$ from $U$ to $V$, as $f: U \rightarrow \wp(V)$ and $u_{i} \mapsto \underset{\sim}{f}\left(u_{i}\right) \in \wp(V)$. A linear transformation $\underset{\sim f}{T}$ between $U$ and $V$ can be induced from $f$, which can be regarded as comprehensive judgement $\underset{\sim}{B}$ reached from weight set $A$.

The fuzzy relationship $\underset{\sim}{R} \in \wp(U \times V)$ can thus be concluded from the fuzzy mapping $f$, which could also be presented as $\underset{\sim}{R}\left(u_{i}, v_{h}\right)=\underset{\sim}{f}\left(u_{i}\right)\left(v_{h}\right)=r_{i h}$, in which $\underset{\sim}{R}$ is also a fuzzy matrix $\underset{\sim}{R} \in \mu_{m \times k} . \underset{\sim}{R}$ is here the single factor judgement matrix, in which $r_{i h}$ is the degree of membership of factor $x_{i}$ be judged as $v_{h}$, and $i=1,2, \cdots, m, h=1,2, \cdots, k$. Specifically, $r_{i h}$ is the frequency distribution of the $i$ th factor $x_{i}$ on the $h$ th judgement $v_{h}$, and $\sum_{h=1}^{k} r_{i h}=1$ after normalization. Matrix $\underset{\sim}{R}$ is then beyond any special treatment for it is of no dimension.

\section{B. Calculation of Fuzzy Comprehensive Evaluation Value}

The fuzzy linear transfer $\underset{\sim}{T}$ from $U$ to $V$ can be incurred from the fuzzy relationship $\underset{\sim}{R}$, and a fuzzy comprehensive evaluation model $(U, V, \underset{\sim}{R})$ is composed.

A weighted average model is imposed on weight $W$ and fuzzy matrix $\underset{\sim}{R}$ for compositional operation, say $M(\cdot,+)$, to have an integrated evaluation of each index on the employment competitiveness. The comprehensive evaluation formula is

$$
\underset{\sim}{B}=W \cdot \underset{\sim}{R}
$$

with the function of a transformer as follow:

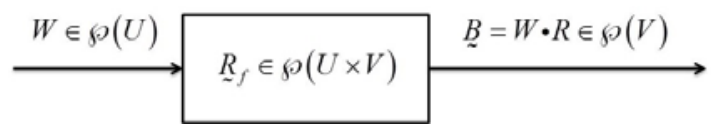


A comprehensive evaluation is output for each input of weight :

$$
\underset{\sim}{B}=W \bullet \underset{\sim}{R} \in \wp(V)
$$

Normalization is to be carried out to let $\bar{\sim}_{h}=\underset{\sim}{b} / \sum_{h=1}^{k} \underset{\sim h}{b_{h}}$, so $\underset{\sim}{\bar{B}}=\left(\bar{b}_{\sim}, \bar{b}_{2}, \ldots, \bar{\sim}_{k}\right)$, when $\underset{\sim}{\bar{B}}=\left(\bar{b}_{1}, \bar{b}_{2}, \ldots, \bar{\sim}_{k}\right)$.

According to the principles of fuzzy distribution, each index in $\underset{\sim}{\bar{B}}$ indicates the distribution status of evaluation target. In order to avoid possible missing evaluation information, a score set $F=\left(f_{1}, f_{2}, \ldots, f_{k}\right)$ is here introduced as a column vector, in which $f_{h}$ is the score of the $h$ th index in the form of Lester scale $F=(20,40,60,80,100)$. Finally, the comprehensive evaluation is gained through multiplication of degree of membership matrix and score set, $Z=\underset{\sim}{\bar{B}} \square F$, in which $Z$ is the final fuzzy evaluation score of employment quality.

\section{EMPIRICAL ANALYSIS}

\section{A. Source of Data}

An empirical analysis is provided in this paper with above method on the employment quality of graduates from Beijing University of Technology (BJUT) in the year of 2015. 1755 effective questionnaires have been obtained, among which 1104 are from graduates covering 37.31\% of the total of 2959. The distribution of the samples is as follow:

TABLE III. DISTRIBUTION OF EFFECTIVE QUESTIONNAIRES ON GRADUATES EMPLOYMENT QUALITY OF BJUT IN 2015

\begin{tabular}{|c|c|c|}
\hline school & copies & ratio \\
\hline Material Science & 29 & $31.52 \%$ \\
\hline Electronic Control & 79 & $23.94 \%$ \\
\hline Environmental Energy & 48 & $34.29 \%$ \\
\hline Mechanical Engineering & 55 & $36.91 \%$ \\
\hline Computer Science & 116 & $48.95 \%$ \\
\hline Civil Engineering & 90 & $34.88 \%$ \\
\hline Pilot College & 198 & $48.18 \%$ \\
\hline Mathematics and Physics & 47 & $34.31 \%$ \\
\hline Construction & 40 & $30.08 \%$ \\
\hline Transportation & 9 & $27.27 \%$ \\
\hline Economics and Management & 98 & $34.39 \%$ \\
\hline Humanity & 50 & $40.00 \%$ \\
\hline Software & 30 & $27.27 \%$ \\
\hline Life & 24 & $28.92 \%$ \\
\hline Foreign Languages & 25 & $30.49 \%$ \\
\hline Art and Design & 166 & $46.89 \%$ \\
\hline
\end{tabular}

\section{B. Data Reduction}

The comment set consists of 5 employment quality status, with expression forms defined for explicit concrete contexts embodied in the questionnaire. All data acquired from the questionnaire are to be reduced to 5 states with grade specific gravity for the degree of membership matrix. Sufficiency and acknowledgement of questionnaire objects are guarantee of the reliability of the evaluation, while in this case, enough feedbacks are available for the questionnaire and all the graduates as the questionnaire objects are the direct carrier of employment quality.

TABLE IV. DEGREE OF MEMBERSHIP OF EMPLOYMENT QUALITY OF SCHOOL OF MATERIAL SCIENCE GRADUATES OF BJUT IN 2015

\begin{tabular}{|c|c|c|c|c|c|c|}
\hline \multirow{2}{*}{$\begin{array}{l}\text { 2nd level } \\
\text { indicator }\end{array}$} & \multirow{2}{*}{$\begin{array}{c}\text { 2nd } \\
\text { level } \\
\text { weight }\end{array}$} & \multicolumn{5}{|c|}{ Degree of membership } \\
\hline & & ideal & good & fair & poor & hazard \\
\hline Wages & 0.03 & 0.48 & 0.45 & 0.03 & 0.00 & 0.03 \\
\hline Welfare & 0.10 & 0.66 & 0.24 & 0.00 & 0.00 & 0.10 \\
\hline $\begin{array}{c}\text { Working } \\
\text { environment }\end{array}$ & 0.03 & 0.72 & 0.24 & 0.00 & 0.00 & 0.03 \\
\hline $\begin{array}{c}\text { Colleague } \\
\text { relationship }\end{array}$ & 0.10 & 0.62 & 0.28 & 0.00 & 0.00 & 0.10 \\
\hline Management & 0.14 & 0.62 & 0.24 & 0.00 & 0.00 & 0.14 \\
\hline Promotion & 0.07 & 0.62 & 0.31 & 0.00 & 0.00 & 0.07 \\
\hline University level & 0.17 & 0.45 & 0.21 & 0.14 & 0.03 & 0.17 \\
\hline School level & 0.28 & 0.45 & 0.24 & 0.00 & 0.03 & 0.28 \\
\hline Career guidance & 0.14 & 0.31 & 0.41 & 0.14 & 0.00 & 0.14 \\
\hline $\begin{array}{l}\text { Employment } \\
\text { policies }\end{array}$ & 0.03 & 0.31 & 0.55 & 0.10 & 0.00 & 0.03 \\
\hline $\begin{array}{c}\begin{array}{c}\text { Employment } \\
\text { services }\end{array} \\
\end{array}$ & 0.07 & 0.34 & 0.38 & 0.21 & 0.00 & 0.07 \\
\hline $\begin{array}{c}\text { Employment } \\
\text { associations }\end{array}$ & 0.03 & 0.17 & 0.31 & 0.31 & 0.17 & 0.03 \\
\hline $\begin{array}{c}\text { Credibility \& } \\
\text { integrity }\end{array}$ & 0.41 & 0.45 & 0.03 & 0.10 & 0.00 & 0.41 \\
\hline $\begin{array}{c}\text { Knowledge } \\
\text { structure }\end{array}$ & 0.03 & 0.38 & 0.41 & 0.07 & 0.10 & 0.03 \\
\hline $\begin{array}{c}\text { Professional } \\
\text { knowledge }\end{array}$ & 0.07 & 0.24 & 0.34 & 0.17 & 0.17 & 0.07 \\
\hline Basic skills & 0.14 & 0.41 & 0.41 & 0.00 & 0.03 & 0.14 \\
\hline $\begin{array}{c}\text { Independent } \\
\text { working ability }\end{array}$ & 0.10 & 0.59 & 0.24 & 0.03 & 0.03 & 0.10 \\
\hline Inter person skills & 0.14 & 0.59 & 0.21 & 0.03 & 0.03 & 0.14 \\
\hline Problem solving & 0.10 & 0.55 & 0.34 & 0.00 & 0.00 & 0.10 \\
\hline Creativity & 0.10 & 0.55 & 0.34 & 0.00 & 0.00 & 0.10 \\
\hline $\begin{array}{c}\text { Knowledge } \\
\text { development }\end{array}$ & 0.10 & 0.59 & 0.31 & 0.00 & 0.00 & 0.10 \\
\hline $\begin{array}{c}\text { Professional } \\
\text { knowledge }\end{array}$ & 0.14 & 0.55 & 0.31 & 0.00 & 0.00 & 0.14 \\
\hline $\begin{array}{c}\text { Basic skills \& } \\
\text { practical ability }\end{array}$ & 0.10 & 0.55 & 0.34 & 0.00 & 0.00 & 0.10 \\
\hline Values & 0.14 & 0.52 & 0.34 & 0.00 & 0.00 & 0.14 \\
\hline \multicolumn{2}{|c|}{ Degree of membership } & 0.13 & 0.49 & 0.30 & 0.07 & 0.02 \\
\hline
\end{tabular}

With School of Material Science as an example, a single factor evaluation matrix $\underset{\sim}{R}$ can be reached from the comments 
of 2nd level indicators. And degree of membership evaluation matrix $\underset{\sim}{T}$ can be obtained as per the formula $\underset{\sim}{B}=W \cdot \underset{\sim}{R}$, with the final comprehensive evaluation 72.88 granted through the multiplication of score set and degree of membership matrix. The overall employment quality and relevant distribution could be acknowledged in this way for the graduates from the School of Material Science, setting up a benchmark for the evaluation on other schools.

\section{RESULTS}

The statistics of employment qualities of graduates from 16 schools of BJUT in the year 2015 are thus chalked up according to the above discussed index and fuzzy evaluation algorithm, as shown in table 5.

TABLE V. FUZZY EVALUATION RESULTS OF EMPLOYMENT QUALITIES OF GJUT GRADUATES IN 2015

\begin{tabular}{|c|c|c|}
\hline Comments & $\begin{array}{c}\text { Ideal, Good, Fair, Poor, } \\
\text { Hazard } \\
\mathbf{( 1 0 0 , 8 0 , 6 0 , 4 0 , 2 0 )}\end{array}$ & Score \\
\hline Material Science & $0.13,0.49,0.30,0.07,0.02$ & 72.88 \\
\hline Electronic Control & $0.24,0.49,0.23,0.03,0.00$ & 78.94 \\
\hline Environmental Energy & $0.16,0.47,0.30,0.04,0.02$ & 74.21 \\
\hline Mechanical Engineering & $0.18,0.52,0.27,0.03,0.00$ & 76.79 \\
\hline Computer Science & $0.20,0.55,0.22,0.02,0.00$ & 78.61 \\
\hline Civil Engineering & $0.17,0.57,0.23,0.02,0.01$ & 77.37 \\
\hline Construction & $0.23,0.44,0.29,0.03,0.00$ & 77.32 \\
\hline Transportation & $0.05,0.55,0.32,0.08,0.00$ & 71.06 \\
\hline $\begin{array}{c}\text { Economics and } \\
\text { Management }\end{array}$ & $0.18,0.52,0.27,0.03,0.01$ & 76.54 \\
\hline Humanity & $0.19,0.57,0.21,0.03,0.01$ & 78.01 \\
\hline Software & $0.21,0.49,0.25,0.05,0.00$ & 76.81 \\
\hline Life & $0.22,0.47,0.24,0.05,0.01$ & 76.80 \\
\hline Pilot College & $0.17,0.48,0.31,0.04,0.01$ & 75.07 \\
\hline Mathematics and Physics & $0.16,0.48,0.27,0.05,0.03$ & 73.87 \\
\hline Foreign Languages & $0.17,0.45,0.33,0.05,0.00$ & 74.88 \\
\hline Art and Design & $0.18,0.44,0.34,0.04,0.01$ & 74.91 \\
\hline
\end{tabular}

A fuzzy evaluation on the questionnaire shows that graduates from the Schools of Electronic Control, Computer Science and Humanity bear the top 3 best employment qualities according to the final scores of 78.94, 78.61 and 78.01. Yet if judged from the degree of membership matrix (24\%, 23\% and 22\%), graduates from the Schools of Electronic Control, Construction and Life show the most optimized ideal status on their employment status. The proposed method could not only provide a bird eye view on the overall employment quality of a school, but also introduce different angles for stratification analysis, proven itself to be a more objective and scientific approach for evaluation of graduates employment quality.

\section{REFERENCES}

[1] Liu Yanru. "Study on the Initial Employment of College Graduates from the Perspective of Social Capital”. PhD Thesis, Central China Normal University, 2012.
[2] Ni Lijuan, Chen Hui. “Analysis on the Factors Restricting the Quality of University Personnel Training”. Heilongjiang Education (Higher Educational Research and Evaluation), vol. 06, pp.40-41, 2007.

[3] Xu Aiqun, Sun Jiang, Qian Suxiang, Zhang Xindi. "Educating the Employment Competition Ability of Undergraduate in Graduation Design”. vol 3, pp. 415-418, 2010. Educational and Information Technology (ICEIT), 2010 International Conference on. IEEE.

[4] Shao Haiya, Wang Di, Wan Yun, Dai Yuezhou, Zhao Bao, Meng Guoxiang. "The Employment Analysis and Training Quality Strategy of Undergraduate on Health Service Management”. Acta Universitatis Medicinalis Nanjing, vol 44(3). pp.194-199, 2011.

[5] Sun Mingbao, Li Xinping. “The Construction of Quality Assessment Index System of Talents Training Based on the Hierarchy Analytic Process - Take an Example of Pedagogical Training in Local Colleges and Institutes”. Journal of Hunan Institute of Science and Technology (Natural Sciences), vol 24, pp.27-30, 2011.

[6] Zhang Dejiang. "Factors Affecting the Quality of Talent Training and the Countermeasures”. China University Teaching, vol 4, pp.11-13, 2012.

[7] Dong Zhuannian, Zhuang Danya, Xu Jingcheng. “The Methods for Improving the Employment Ability of Graduates in Applied Undergraduate Universities_- Taking Huangshan University as an Example”. Journal of Huangshan University, vol 17(1), pp.100-103, 2015..

[8] Nguyen Danh, Yoshinari Yanagawa, Shigeji Miyazaki. "University Education and Employment in Japan: Students' Perceptions on Employment Attributes and Implications for University Education”. Quality Assurance in Education, vol.13(2), pp.202-218, 2005.

[9] Liu Suhua. "The Step and Method to Establishing the Quantitative Evaluation System on Employment Quality in China”. Population \& Economics, vol 6, pp.34-38, 2015.

[10] Ke Yu. "The Construction of College Graduates Employment Quality Evaluation Index System”. China Higher Education, vol 7, pp.82-84, 2007.

[11] Zhang Pei. "Research on Evaluation Index System of Undergraduate Talents Training in Electronic Commerce Specialty” Master’s Degree Thesis. Hefei University of Technology, 2009.

[12] Zhang Yunxia. "On the Evaluation Model of College Talent Training Quality Based on Strategy". Journal of Xinxiang Teachers College (Social Science), vol 26, pp.143-145, 2012.

[13] Dai Ning, Cai Baping. “Construction of Talents Training Quality Standard in Public Security Colleges and Universities from the Perspective of Ability Standard”. Journal of Sichuan Police College, vol 20, pp.62-67, 2008.

[14] Sun Zeping, Qi Xingui, He Wanguo. "Practice and Exploration on the Construction of Applied Talents Training System - Taking Chongqing Academy of Arts and Sciences as an Example". Chongqing Higher Education Research, vol 1, pp.54-58, 2013.

[15] Zhou Yan. "Research on the Construction of the Quality eEvaluation sStandard of Accounting Computerization Specialty in Higher Vocational Colleges”. Knowledge Economy, vol 2, pp.179-180, 2013

[16] Jia Dongrong. “On the Employment Quality of Undergraduates of Nongovernmental Higher Vocational Colleges”. Vocational \& Technical Education, vol 32(10), pp.57-62, 2013.

[17] Yang Qiyong Zhang Jie. "On "Five Satisfactions": Reflection about Quality Assessment System of Undergraduates' Employment”. Journal of Southwest China Normal University, vol 38(1), pp.151-155, 2013

[18] Li Jiangbin, Yu Yongzhu, Huang Guobin, Niu Yujie. "Effects of Research and Innovation Ability on Undergraduate Medical Student's Employment”. Science \& Technology Vision, vol 30, pp.28-28, 2013.

[19] Li Yi. "Enhance Career Planning Education and Improve Employment Quality of Graduate”. Guide of Science \& Education, vol 1, pp.156-157, 2015 